\title{
Women's Reconciliation with the Real World in The Good Apprentice
}

\author{
Mingying Xu \\ Dalian University of Technology, Dalian, China \\ Guiren Shi \\ Liaoning University, Shenyang, China
}

\begin{abstract}
This paper focuses on the reconstruction of female selfhood through Murdoch's elaboration of the multiple ways that the women use to integrate their female self by reconciliating with the real world. It interprets and redefines "self", the core concept of Murdoch's philosophy. Furthermore, it explores the way for the woman to bring the life back to the real world and reconcile with the contingency in life in the novel. It points out that the various ways that the female characters adopt to survive their plights lead them to different destinations that aren't always the places where they want to be, which is precisely the focus of Murdoch's philosophy that how the female could join the human race with a complete self and how they could approach the Good.
\end{abstract}

Index Terms-Iris Murdoch, The Good Apprentice, reconciliation, female self

\section{INTRODUCTION}

Murdoch begins The Good Apprentice with a horrible incident that Edward Baltram kills his best friend Mark Wilson indirectly and unwittingly. Edward cheated Mark into eating a drugged sandwich, hoping he could enjoy a "happy journey" (Murdoch, 1997, p.1), and then left him alone. When he came back from a date with his fellow-student Sarah Plowmain, he found the window in the flat open and Mark lying on the pavement below dead. Suffering from guilt and depression over the incident, Edward puts his feet on the journey of self-forgiving and self-redemption. The Good Apprentice is divided into three sections. The first section "The Prodigal Son" describes Edward's breakdown after the incident. The second one "Seegard" depicts his self-redemptive journey to search for his magic father. And the third one "Life After Death" recounts his bottom out and the restart of his life with more attention and love to others. Along with the main clue of suffering and redemption, Murdoch also explores the possibility of and the likely ways to the integration of female self through the depiction of the female characters' struggle in their own familial, marital, and emotional plights.

In The Good Apprentice, Murdoch reveals the difficulty in the formation of female self by portraying female characters' personal growth through increased awareness of themselves and the relationship with others and the plights of failing "to see the individual because we are completely enclosed in a fantasy world of our own" (Murdoch, 1997, p.216). While Mother May is struggling with the male dominance in the family in order to complete female self, Margaret McCaskerville, known by her nickname "Midge", is experiencing a fierce inner struggle to bring her life back to the real world and reconcile with the contingency in life for the same purpose. Murdoch assigns Midge with a cultured husband Thomas McCaskerville, a psychiatrist whom Midge is "impressed by his prestige, by his power, and by his being grand and older" (Murdoch, 2001, p.171). Unlike Jesse and Mother May, Midge and her husband live together in peace without the exerted authority of the husband in the family. Regardless of "her little air of self-satisfied animation" (Murdoch, 2001, p.22), Midge is an approachable beauty that are highly admired by the people around her. Unfortunately, admiration from others and the decent marriage life fail to bring the real happiness to self-confused Midge who is tangled in the extramarital love affair with Harry. Through the characterization of Midge, Murdoch illustrates how women could identify their self through the reconciliation with the real world and comply with the contingency in it.

\section{COMPROMISE WITH THE REAL WORLD}

In the novel, Midge is depicted as a woman who puts all her effort to prove her worth and her existence through the approbation of others and the triumph in the competition for attention and admiration. So there is no doubt that her ambition doesn't lie in the self-improvement in education and personal career. After "her short career as a fashion model" (Murdoch, 2001, p.5), Midge does nothing but to busy herself with such consolations as flowers and clothes that "slowed the pace of the world toward a point of absolute repose" (Murdoch, 2001, p.135) for her. Midge reacts less positively to her friend's suggestion that she should get herself out of house and have some education to get rid of harmful idleness and her complaints about being ignorant. 
Midge has been growing under the shadow of her sister Chloe as the "invisible" (Murdoch, 2001, p.86) little sister, Sibling rivalry is "in full bloom and wreaking havoc" (Khogeer, 2005, p.126) in the relationship between them. Her jealousy of Chloe's "beauty, charm, intelligence and vivaciousness" (Khogeer, 2005, p.126) provokes her hatred to her sister and drives her to "be plagued by a dilapidating and almost crippling inferiority complex" (Khogeer, 2005, p.126). Eager to be approved and appreciated, Midge starts from scratch when she "looked like nothing at all" (Murdoch, 2001, p.86). Compared with Harry who is made "by [his] father, [his] childhood, [his] school, [his] education, [his] money" (Murdoch, 2001, p.86), Midge is exhausted to "invent myself out of nothing" (Murdoch, 2001, p.86). It is "one of [her] aims in life" for Midge "to triumph over Chloe" (Murdoch, 2001, p.345). With her sexual awakening brought by a careless glimpse of Chloe's lover Jesse Baltram who is "a great dominating powerful man" (Murdoch, 2001, p.88) in her mind, Midge spends years "busy inventing [herself]" (Murdoch, 2001, p.86) and finally becomes a more famous fashion model than Chloe, which proves the assertion of her father and her sister that she has no talents to be completely wrong. And her two-year illicit affair with Chloe's husband Harry, Chloe's death and Jesse's kissing her means her clear victory over Chloe since "[t]here's nothing more [she] can take away from the poor girl” (Murdoch, 2001, p.345). In the competition with her sister Chloe for attention and appreciation, Midge shapes her self-perception on the basis of the affirmation from others and the comparison with others. The days when Chloe was everything and Midge was nothing pass, and Midge does believe she is not a shadow of Chloe, "a substitute, a second-best" (Murdoch, 2001, p.88) any more. Once she finds herself completely overwhelm Chloe, she feels the meaninglessness of her competitiveness in the past years and gets involved in the estrangement with the real world concerning how to confront her husband and her lover in her life, which results from her blind pursuit of triumph over her sister.

Although the men in her life, from her husband Thomas to her lover Harry, are showing considerable respect to women, they are all scornful of women's "lost bad spirit" (Murdoch, 2001, p.30), that is "spirit without absolute" (Murdoch, 2001, p.30), which shakes the traditional dominate position of men:

Women are always a touchstone, ... like litmus paper or dogs before an earthquake, look at them now running round in manic excitement, they're destroying the old order you're so fond of, men are terrified, no wonder Islam is the most popular religion in the world! (Murdoch, 2001, p.30)

Furthermore, they still firmly believes in the necessity of absolute discourse power that "will be reserved for the creative few ... who have all the power" as "the only individuals left" (Murdoch, 2001, p.30), while "the ordinary mob will simply be codified manifestations of a generalized technological consciousness" (Murdoch, 2001, p.30). And Murdoch summarizes the men's general attitudes to women who "have to make everything personal" (Murdoch, 2001, p.30) through comments of Midge's female friend on Harry:

I can't stand these prophets of doom, gloating over the collapse of civilisation, they're always anit-women. I think Harry despises women, well I suppose most men do. Poor old planet all the same. No wonder Dirk Plowmain shot himself. (Murdoch, 2001, p.34)

Here Murdoch refocuses on the prevailing prejudice against women and the limited improvement in women's status.

Though deeply loved by both her husband and her lover, Midge is not free from the restriction of the male. According to their friends opinion, Midge is not ideally matched with her husband since "Thomas ought to have married a busy Scottish body who was always in the kitchen, and Midge ought to have married a rich industrialist with a yacht who would enable her to have a salon full of the rich and famous" (Murdoch, 2001, p.362). As "an autocrat and a bully" (Murdoch, 2001, p.362), Thomas fails to detect her subtle psychological changes and emotional needs, which implants in Midge that "he is not thinking about [her] at all, he deserves to lose [her], he thinks all [her] activities are a form of play" (Murdoch, 2001, p.136). Dissatisfied with her marital life, Midge turns to her lover Harry for happiness and sense of triumph over Chloe. However, Harry's love for her is so aggressive that he likes "Midge to wait upstairs like a captive bride" (Murdoch, 2001, p.168) and urges her to have a showdown with her husband for divorce, though they agreed to continue their affair on the premise that they keep it a secret to Thomas.

Indulged in the happiness brought by the extramarital affair and the sense of security from the family, Midge is reluctant to choose between Harry and Thomas. With "a look of evasive hunted irritation ... and dreaded" (Murdoch, 2001, p.90), Midge is caught in a dilemma: she loves Harry absolutely, but she couldn't stop worrying and caring about Thomas. Harry points out the unreality of her life to her:

You live a sort of permanent double life where everything is true except that it isn't. When you're with me Thomas doesn't exist, when you're with Thomas I don't exist. If the deception succeeds perfectly you can dream that nothing's happening, that you're innocent. (Murdoch, 2001, p.170)

Midge attempts to lower her husband's position in her heart to assuage the guilt, deceiving herself that her feeling for Thomas has "become dark and in the dark it's diminishing, like a little animal left somewhere to die and you come every day and hope that it's dead and it's still twitching and it's still breathing" (Murdoch, 2001, p.170). So she "must untie [herself] from Thomas, undo [herself], quietly patiently thoroughly untie every little bond, cut every little vein" (Murdoch, 2001, p.172) to "make a great blank where he is, make him into a zombie in my mind, then it won't hurt so" (Murdoch, 2001, p.172). On one hand, Midge is highly aware of her own state and what she wants: "I'm not happy, I'm miserable, I'm in hell, and that's all wrong, it isn't me. I must be happy, it's my nature, it's my right" (Murdoch, 2001, p.205). On the other hand, she is afraid to break down "the customary modes of gentleness and concern and ordinary instinctive communication and politeness were ever, between her and Thomas" (Murdoch, 2001, p.205). And she is 
afraid to change herself for someone being "liked and petted" by everybody to someone who caused "such grief, such scandal and such chaos" (Murdoch, 2001, p.204). The irresolution makes "her face wrinkled in frightened evasive anxiety" (Murdoch, 2001, p.173) and her "losing [her] identity" which she "never had much anyway" (Murdoch, 2001, p.206). In order to "preserve her sanity" (Murdoch, 2001, p.203), she feels like to "do something ... like to break something or jump into a river or out of the window, it's like wanting to brush something off, like a purification" (Murdoch, 2001, p.203).

Midge's fear to make a choice is actually rooted in her escaping self from the reality. The contingent event happened at Seegard is revealed by Mother May in her diary that is published by a well read newspaper, which brings Midge's illicit affair with Harry to the light and forces her to make a prompt decision. Midge's self-recognition and identity that are based on the double life collapse so completely that "[i]t was as if there was nothing left in her life up to now with which she could either rest or work" (Murdoch, 2001, p.460).

The guilt, the disloyalty, the lies, the hurt and harm done to others, must be seen as real. But Midge, in attempting so to see it, did not consider it as a place where there were for her any stepping stones, any possibility of reconstruction, renovation, explanation, acts of healing. The collapse was, she reckoned, too complete for that she could not do good, and only stain her hands further, by going back, however well intentioned, into that mess. (Murdoch, 2001, pp.460-61)

So far, Midge still tries to escape from the reality that she must face her self-identity crisis with the courage to tell the truth instead of "convincing herself of its horror and completeness and of her guilt with which she could do nothing except somehow leave it behind" (Murdoch, 2001, p.460). As a witness to Midge's embarrassment from the exposure of her illicit affair with Harry and from her passionate kiss with Jesse at Seegard, Stuart is regarded by Midge as "an obsessive image" (Murdoch, 2001, p.333) who "in his detestable role of witness and judge, had "got into her" (Murdoch, 2001, p.333) for "a word from his could destroy us" (Murdoch, 2001, p.333). At that moment, Midge feels that "[e]verything [she]'d wanted just became worthless, as if [she] didn't want anything anymore" (Murdoch, 2001, p.367) and decides to change her life and "do some good in the world" (Murdoch, 2001, p.367) just like Stuart. So soon after Midge comes back from Seegard, she thinks that she has fallen in love with Stuart, which is her way to "dismiss him, to defeat him, and by voicing her contempt for his opinions to make it efficacious and real" (Murdoch, 2001, p.333). Lacking introspection, Midge turns to Stuart for "a sort of absolution ... some forgiving understanding, compassion, feeling -" (Murdoch, 2001, p.368). With the alternative to make the difficult choice, Midge feels "soothed ... as if her whole body was being remade, as if by radiation, the atoms of it changed" (Murdoch, 2001, p.369).

Murdoch depicts Midge's avoidance of confronting the real world as "a diversion, another emotional experience, a way of experiencing - of continuing - that relationship" (Murdoch, 2001, p.366), which leads Midge to live nowhere but "in some sort of dream" (Murdoch, 2001, p.366) and determines "her altered self" (Murdoch, 2001, p.369), though "entirely new" (Murdoch, 2001, p.369), to be unreliable. Seemingly enlightened, Midge considers her life "so idle, so useless, so full of vanity" (Murdoch, 2001, p.371) that she must force Stuart to "take responsibility for [her]... recognize [her] and acknowledge [her]" (Murdoch, 2001, p.371). Failing to realize the impossibility of happiness in a deception, Midge toughly believes that Stuart is the only hope to save and comfort her. However, firmly declining Midge's court, Stuart disagrees with her assertion that "[f]alling in love is a renewal of life" (Murdoch, 2001, p.330), but reminds her that she should renew her life by realizing how much she loves her son and her husband because "[t]elling a lot of lies, particularly systematic lies, gradually detaches one from reality, one can't see" (Murdoch, 2001, p.366). So the point is to tell the truth since "[t]elling him is what will make everything clear and real" (Murdoch, 2001, p.366).

Encouraged by Stuart and determined to change herself, Midge takes her first step on her way to the real world by confessing to Harry her decision to leave him though "[o]ld deep habits of love and loyalty fought for life against the new revelation" (Murdoch, 2001, p.370). After her confession, she feels "a kind of relief" (Murdoch, 2001, p.398), though "miserable" (Murdoch, 2001, p.398):

I can tell the truth. I've always been afraid of saying what I really thought, I've evaded direct questions, always hidden in half-truths. All those endless lies had got into me so that I couldn't talk properly to anyone, as if I had no truthful language at all - it made me into a puppet, something unreal, we were unreal, I've often felt that. (Murdoch, 2001, p.398)

Then, the exposure of her illicit affair by Mother May drives her to confess passively to her husband her love affair with Harry and her decision to stop it and then to love Stuart, which makes Thomas leave home angrily. Obsessed by "his commanding being, his authority, his separateness, his inaccessibility, his unconnectedness with other people" (Murdoch, 2001, p.462) that will save her from "a fall to death" (Murdoch, 2001, p.462), Midge fails to really understand Stuart's point on her issue until her talk with Edward makes her come to an understanding all of a sudden.

As "a candid intelligent well-intentioned on-looker" (Murdoch, 2001, p.485), Edward points out that Midge's falling in love with Stuart is just "an escape from choice" (Murdoch, 2001, p.469) in order to prevent her from thinking about Thomas and Harry. Since all happen just in her mind, Stuart is "just an external impulse, a sort of jolt, a solid entity, something [she] bump[s] into" (Murdoch, 2001, p.469).

Taking it in, Edward had, quickly intuitively, touched her state of mind, pressing its structure at vulnerable and unstable points. His cry 'it's mad, it's daft, it must be false!' about her love for Stuart had startled her like the war cry of 
a new force. It was possible to see 'the event' in a different light, not losing faith in it, but receiving in relation to it, more space more play. (Murdoch, 2001, pp.485-86)

Realizing that her love with Stuart is just "a means by which she had separated herself from Harry" (Murdoch, 2001, p.486), Midge decides to return to family. By accident, her husband Thomas goes back home at this moment after his running away for her affair with Harry. "The not-lying made everything so completely different, and of course not as it once was" (Murdoch, 2001, p.488). Reconciling with the real world, Midge unmakes herself and finally realizes what's of the most importance in her life.

She could not have survived that rupture, that desertion, that flight, that had seemed so beautiful in the unreal prospect of it, to leave Thomas behind and Meredith torn in two, and live a new free life with Harry, casting off the past. It had only seemed possible because it was really out of the question, something not really imagined, a fantasy coexisting with a reality which excluded it. (Murdoch, 2001, p.490)

The reconciliation with the reality finally helps Midge "out of this cage of lies and pain at last" (Murdoch, 2001, p.204) and free to "discover all her old feelings for Thomas, or rather to find out what had been happening to them, as if she had come back to find the grown, developed, refined, and most evidently powerful” (Murdoch, 2001, p.491).

\section{ACCEPTANCE OF THE CONTINGENCY IN THE REAL WORLD}

Besides the reconciliation with the real world, Murdoch also emphasizes the importance of accepting the contingency in the real world. "[A]ll sorts of things ... happened by pure chance. At so many points anything being otherwise could have made everything be otherwise" (Murdoch, 2001, pp.517-18). In the process of integrating female self, Midge's personal growth is full of contingency so that she can't help wondering:

Supposing that confident key in the door had been Harry's and not Thomas's? It was all chance of else the opposite, something arranged by God. Edward's arrival for instance. (Murdoch, 2001, p.485)

Midge's "self-authenticating experience" (Murdoch, 2001, p.491) makes her "aware that all the good things she felt sure she was destined to do would perhaps after all turn out to be the dull old familiar things, the duties of her family and her home (Murdoch, 2001, p.490)" since "[s]ometimes such fates could not be avoided, but here it would have been wanton" (Murdoch, 2001, p.490).

For the sake of the analysis of female characters, self-consciousness is interpreted as the ability to introspect and examine one's inner self, desires and feelings in order to know oneself as an individual while inner life could be interpreted as the continual process of self-cognition that makes an individual definable and recognizable in interpersonal relationships. As identity formation is the process of the development of the distinct personality of an individual and the inner life deals with the individual in relation, self could be understood as the substantial nature of an individual that enables him/her to have a full understanding of oneself with self-consciousness and to be definable and recognizable in the relations with self-identity on the reception of reality. Moreover, , selfhood refers to the fully developed self achieved by the connection to others through "attention" (Murdoch, 1997, p.327). The application of these concepts to the character analysis reveals the progressive, though sometimes overlapping before and after, changes in Murdoch's characterization of female characters. Murdoch's focus on the female in her novels shifts from women's self-redemption from the crushing traditional selfhood imposed by the patriarchy, to their self-improvement to be conscious of themselves, to their self-knowledge of their identity in the real life, and finally to the integration of the female self to reconcile with the real world.

While Mother May is struggling with the male dominance in the family in order to complete female self, Midge is experiencing a fierce inner struggle to bring her life back to the real world and reconcile with the contingency in life for the same purpose. Different from Mother May's internecine fight against the male dominance, Midge's inner struggle against her own self-centered pursuit for happiness and her fundamental lack of understanding of the reality leads her to the reconciliation with the real world which of full of contingency and finally completes her female self. From the characterizations of these female characters, Murdoch illustrates that blind hatred and revenge as well the lies all hinder women from the integration of female self and from reaching the state of Goodness. Different from Mother May's internecine fight against the male dominance, Midge's inner struggle against her own self-centered pursuit for happiness and her fundamental lack of understanding of the reality leads her to the reconciliation with the real world which is full of contingency and finally completes her female self. From the characterizations of these female characters, Murdoch illustrates that blind hatred and revenge as well the lies all hinder women from the integration of female self and from reaching the state of Goodness.

\section{CONCLUSION}

While Murdoch conveys her philosophical thoughts in her novels, her creation of characters and plots in turn enriches and deepens her philosophy. Reluctant to respond directly to the question on women's liberation and gender equality, Murdoch says that she identifies with men more than women and expresses her willingness to help women "join the human race" (Dooley, 2003, p.83) but not make "any land of feminine contribution" (Dooley, 2003, p.48) since both men and women are human beings. But when it comes to the realistic description of women's situation, her theoretical impartiality becomes impracticable. Besides the character development of women figures, Murdoch also 
reflects the sociocultural changes impacted on the women social status through impartial description of male-female relationships. However, Murdoch implies that there is still a long way for women to really "join the human race" (Dooley, 2003, p. 83) as there have been a few male characters who have reach the state of being good, the highest state of Murdoch's morality, but there are no women who achieve it even though some of them are on their way to approach it.

\section{ACKNOWLEDGEMENT}

Project Supported by “the Fundamental Research Funds for the Central Universities" (Grant No. DUT14RW212) and by Liaoning Social Science Fund, China (Grant No. L13BYY010)

\section{REFERENCES}

[1] Dooley, Gillian. (2003). From a Tiny Corner in the House of Fiction: Conversations with Iris Murdoch. Columbia: University of South Carolina Press.

[2] Khogeer, Afaf Jamil. (2005). The Integration of the Self: Women in the Fiction of Iris Murdoch and Margaret Drabble. New York: University Press of America.

[3] Murdoch, Iris. (1997). Existentialists and Mystics: Writings on Philosophy and Literature. Peter J. Conradi \& Allen Lane (eds.). London: Chatto \& Windus.

[4] Murdoch, Iris. (2001). The Good Apprentice. New York: Penguin Books.

Mingying Xu was born in Harbin, China in 1977. She received her PH.D. degree in English Language and Literature from Shanghai International Studies University, China in 2013.

She is currently an associate professor in the School of Foreign Languages, Dalian University of Technology, Dalian, China. Her research interests include British and American literature and literary criticism.

Guiren Shi, was born in Shenyang, China in 1962. He is currently a professor in College of Foreign Studies, Liaoning University, Shenyang, China. His research interests include British and American Literature and English Culture. 